\section{Caribbean Community (CARICOM)}

Origin. The Treaty of Chaguaramas establishing the Caribbean Community and Common Market was signed by the prime ministers of Barbados, Guyana, Jamaica and Trinidad and Tobago at Chaguaramas, Trinidad, on 4 July 1973.

Six additional countries and territories (Belize, Dominica, Grenada, St Lucia, St Vincent and the Grenadines, Montserrat) signed the Treaty on 17 April 1974, and the Treaty came into effect for those countries on 1 May 1974. Antigua acceded to membership on 4 July that year; St Kitts and Nevis on 26 July; The Bahamas on 4 July 1983 (not Common Market); Suriname on 4 July 1995.

Members. Antigua and Barbuda, The Bahamas, Barbados, Belize, Dominica, Grenada, Guyana, Haiti, Jamaica, Montserrat, St Kitts and Nevis, St Lucia, St Vincent and the Grenadines, Suriname, and Trinidad and Tobago. Anguilla, Bermuda, the British Virgin Islands, the Cayman Islands and the Turks and Caicos Islands are associate members.

Objectives. The Caribbean Community has the following objectives: improved standards of living and work; full employment of labour and other factors of production; accelerated, co-ordinated and sustained economic development and convergence; expansion of trade and economic relations with third States; enhanced levels of international competitiveness; organization for increased production and productivity; the achievement of a greater measure of economic leverage and effectiveness of member states in dealing with third States, groups of States and entities of any description; enhanced co-ordination of member states' foreign and foreign economic policies; enhanced functional co-operation.

At its 20th Meeting in July 1999 the Conference of Heads of Government of the Caribbean Community approved for signature the agreement establishing the Caribbean Court of Justice. They mandated the establishment of a Preparatory Committee comprising the Attorneys General of Barbados, Guyana, Jamaica, St Kitts and Nevis, St Lucia and Trinidad and Tobago assisted by other officials, to develop and implement a programme of public education within the Caribbean Community and to make appropriate arrangements for the inauguration of the Caribbean Court of Justice prior to the establishment of the CARICOM Single Market and Economy. To this end at its 23rd Meeting in July 2002 the Heads of Government agreed on immediate measures to inaugurate the Court by the second half of 2003, although delays meant it was not inaugurated until April 2005. Among the measures adopted was the establishment of a Trust Fund with a one-time settlement of US $\$ 100 \mathrm{~m}$. to finance the Court.

Structure. The Conference of Heads of Government is the principal organ of the Community, and its primary responsibility is to determine and provide the policy direction for the Community. It is the final authority on behalf of the Community for the conclusion of treaties and for entering into relationships between the Community and international organizations and States. It is responsible for financial arrangements to meet the expenses of the Community.

The Community Council of Ministers is the second highest organ of the Community and consists of Ministers of Government responsible for Community Affairs. The Community Council has primary responsibility for the development of Community strategic planning and co-ordination in the areas of economic integration, functional co-operation and external relations.

The Secretariat is the principal administrative organ of the Community. The Secretary-General is appointed by the Conference (on the recommendation of the Community Council) for a term not exceeding five years, and may be reappointed. The SecretaryGeneral is the Chief Executive Officer of the Community and acts in that capacity at all meetings of the Community Organs.
Associate Institutions. Caribbean Development Bank (CDB); University of Guyana (UG); University of the West Indies (UWI); Caribbean Law Institute (CLI)/Caribbean Law Institute Centre (CLIC); Organisation of Eastern Caribbean States.

Official language: English.

Headquarters: Caribbean Community (CARICOM) Secretariat,

Turkeyen, Greater Georgetown, Guyana.

Website: http://www.caricom.org

Email: registry@caricom.org

Secretary-General: Irwin LaRocque (Dominica).

\section{Further Reading}

Payne, Anthony, The Political History of CARICOM. 2007

\section{Caribbean Development Bank (CDB)}

Established in 1969 by 16 regional and two non-regional members. Membership is open to all states and territories of the region and to non-regional states that are members of the UN or its Specialized Agencies or of the International Atomic Energy Agency.

Members-regional countries and territories: Anguilla, Antigua and Barbuda, The Bahamas, Barbados, Belize, British Virgin Islands, Cayman Islands, Dominica, Grenada, Guyana, Haiti, Jamaica, Montserrat, St Kitts and Nevis, St Lucia, St Vincent and the Grenadines, Suriname, Trinidad and Tobago, Turks and Caicos Islands. Other regional countries: Brazil, Colombia, Mexico, Venezuela. Non-regional countries: Canada, China, Germany, Italy, United Kingdom.

Function. To contribute to the economic growth and development of the member countries of the Caribbean and promote economic co-operation and integration among them, with particular regard to the needs of the less developed countries.

Headquarters: PO Box 408, Wildey, St Michael, Barbados, WI BB11000.

Website: http://www.caribank.org

Email: info@caribank.org

President: William Warren Smith (Jamaica).

\section{Central American Bank for Economic Integration (CABEI)}

Established in 1960, the Bank is the financial institution created by the Central American Economic Integration Treaty and aims to implement the economic integration and balanced economic growth of the member states.

Regional members. Costa Rica, El Salvador, Guatemala, Honduras, Nicaragua.

Non-regional members. Argentina, Belize, Colombia, Dominican Republic, Mexico, Panama, Spain, Taiwan.

Official languages: Spanish and English.

Headquarters: Apartado Postal 772, Tegucigalpa,

DC, Honduras.

Website: http://www.bcie.org

President: Dr Nick Rischbieth (Honduras). 